\title{
INFLUENCE OF OXYGENATOR EXTRACORPORAL CIRCUIT TREATMENT WITH ADAPTATION COMPOSITION (ADC) ON MORPHOLOGICAL CHANGES OF ERYTHROCYTES
}

\author{
V. I. Cherniy', L. O. Sobanska' ${ }^{1}$, O. M. Lazarenko', G. 0. Lazarenko', T. A. Alekseeva ${ }^{2}$ \\ ${ }^{1}$ State Institution of Science «Research and Practical Center of Preventive and Clinical Medicine» State Administrative Department, Kyiv, Ukraine \\ ${ }^{2}$ Chuiko Institute of Surface Chemistry of the National Academy of Sciences of Ukraine, Kyiv, Ukraine
}

\section{Summary}

Background. The study highlights a method of treatment extracorporeal circuit with «adaptation composition» (AdC) for the reduction of negative impact on state of erythrocytes.

Aim: to assess the effect of treatment the contact surface extracorporeal circuit with «adaptation composition» $(\mathrm{AdC})$ on changes in the state of erythrocytes after open-heart surgery with cardiopulmonary bypass $(\mathrm{CPB})$.

Material and methods. A total of 90 patients were enrolled, they were divided into two groups. The group 1 (45 patients, 39/6 male/female) included patients who underwent surgical procedures without treatment of an extracorporeal circuit with AdC. The group 2 (45 patients, 39/6 male/female) included patients who underwent surgery with the treatment of an extracorporeal circuit with AdC. According to the study protocol, patient blood was sampling for complete blood cell count $(\mathrm{CBC})$ and erythrocyte morphology at 4 stages of surgery: before surgery, at $10 \mathrm{~min}$. CPB-time, at $60 \mathrm{~min}$. CPB-time and after separation from CPB.

Results. The albumin of AdC creates a protective nanolayer on the surface of the oxygenator membrane and tubes. There were no statistically significant differences of parameters in the groups before CPB. Level of Ht 2 (group 2) at 60 min CPB-time and after CPB, were lower than Ht 1 (group 1) ( $\mathrm{p}=0.021$ and $\mathrm{p}=0.035$ correspondingly) because MCV1 was higher ( $\mathrm{p}=0.025$ and $\mathrm{p}<0.0001$ correspondingly). The increase MCHC in groups at $10 \mathrm{~min}$. CPB-time relatives with the decrease in MCV at $10 \mathrm{~min}$ CPBtime. At $60 \mathrm{~min}$, there are changes of RDWa2 $76.05 \pm 5.46$ and RDWa1 $72.35 \pm 7.26, \mathrm{p}<0.000$. After CPB higher content of reticulocytes $(p<0.0001)$, echinocytes $(p<0.0001)$ and spherocytes $(p<0.0001)$ is observed in group 1 . The lowering of mechanical resistance $(p=0.04)$ and increasing membrane permeability for urea were in group 1 . After CPB the best acid hemolysis resistance was in group 2 $(p=0.05)$, erythrocytes were more resistant to hypoosmotic factor $(p=0.01)$ in group 2.

Conclusion. The treatment of oxygenator with AdC reduces the negative influence CPB on state of RBC. Membranes of erythrocytes were more resistant to traumatic factors in the group with AdC.

Key words: cardiopulmonary bypass, oxygenator, erythrocyte morphology, adaptation composition.

\section{INTRODUCTION}

A special biological function is performed by the erythrocyte membrane as a universal model that reflects the state of the membranes of the whole organism. Cell membranes are the first target when are influenced by hypoxia, their changes can serve as an early signal of the pathological process [1]. During heart surgery, the problem of hypoxia and its prevention remains a priority. Membranes of the oxygenator are the active part of the device, where blood oxygenation is taken place. Unfortunately, for the patient's organism, its surface is an exogenous material that leads to the adsorbtion of erythrocytes and the adhesion of leukocytes, which in turn provokes an inflammatory response [2-6]. All cells of the blood are sensitive to these factors and can be irreversibly damaged.

On the other hand, in our previous study [7] it was shown that the adsorbtion of erythrocytes leads to a decrease in cell metabolism on the membrane of the oxygenator and a decrease in the number of the oxygenated erythrocytes was associated with it. This phenomenon is 
accompanied by changes in the shape and state of red blood cells. Changes in the shape of erythrocytes can give some information about the intensity of the pathological process [8]. In normal human blood, the discocytes (erythrocytes of biconcave shape) are the main bulk (80-90\%). In addition, there are planocytes (with a flat surface) and aging forms of erythrocytes:

- spiny erythrocytes or echinocytes (about 6\%)

- domed erythrocytes or stomatocytes (about 1-3\%)

- spherical erythrocytes or spherocytes (about 1\%).

The process of changing the shape of an erythrocyte is its transformation from a disk to a spherical shape. This process is carried out in two ways: 1) echinocytosis when the surface of the erythrocyte is covered with cone-shaped spines. This occurs under the action of fatty acids, ATP deficiency, increased $\mathrm{pH}$. Echinocytes are often formed when suspending erythrocytes in an isotonic environment and the addition of albumin can return the cells to a normal discocyte form and 2) stomatocytosis when the erythrocyte retains a smooth surface but takes the shape of a unilaterally concave disc and one has an increased volume and area of $20-30 \%$. This occurs when the $\mathrm{pH}$ is lowered and under the influence of drugs. Echinocyte and stomatocyte are the reverse forms of erythrocyte, and spherocyte is the most rigid structure of erythrocyte, which is irreversible and precedes cell destruction [8]. Cell death occurs either through necrosis and apoptosis. These are opposite forms both in regard to the reasons causing them and to the mechanism of development. A sign of cell necrosis is more often its swelling (necrotic increase in cell volume), and a decrease in cell volume prevails in apoptosis (apoptotic decrease in cell volume). Echinocytes are preapoptotic cells and stomatocytes are prenecrotic [16].

The resistance of erythrocytes to various influences of internal and external environments is also caused by a condition of its cell membrane. Normal permeability of the cytomembrane is the main requirement in cell homeostasis. Decreased resistance of erythrocytes in hypoxia leads to increased hemolysis. Previously, hemolysis in the process of CPB was considered only as mechanical damage of erythrocytes as a result of cardiotomy suction power, roller pump capacity, the presence of an arterial filter and turbulent flows in places of transitional diameters of the extracorporeal circuit. The measurement of plasma free hemoglobin (plfHb) concentration to characterize hemolysis is a routine method but sublethal trauma of RBC is more difficult to detect because no simple direct test exists. The concept of sublethal RBC damage was introduced by Dr. Galletti [17, 18]. The study of erythrocyte membrane resistance allows us to judge the resistance of erythrocytes to deformation and $\mathrm{RBC}$ mechanical fragility within the conditions of CPB [9]. One of the main goals to reduce intraoperative hemolysis was to develop the most biocompatible components of the extracorporeal circuit. In this regard, it is important to simultaneously conduct a comprehensive assessment of the resistance of erythrocytes to various hemolytic factors and the permeability of their plasma membrane. In clinical practice, there is a need for an available assessment method of the functional status of the erythrocyte's membrane.

An appropriate way to assess the structural and functional state of erythrocytes is to determine the resistance of blood cells to various factors - mechanical, osmotic and acidic. We extrapolate to the hemolysis time of red cells.

By contrast with most other cells, erythrocytes placed in an acidic medium undergo a high-grade hemolytic reaction (necrosis). It is known that the acid resistance of erythrocytes mainly reflects the state of the phospholipid bilayer and erythrocyte membrane proteins. The main target of acid hemolysis is membrane proteins and cell destruction is preceded by the effect of hemolysin on structural elements of a membrane and the transport of this lysing agent into the cell, which may be the result of harmful effects of the agent and pore formation in the lipid bilayer [10].

Osmotic resistance of erythrocytes (ORE) generally characterizes the state of the cytoskeleton of cells. Osmotic hemolysis occurs when a cell enters a hypotonic environment. Hypotonic solutions lead to cell swelling and lysis if the osmotic movement of water is great enough.

Urea molecules upon the concentration gradient penetrate through the pores into the cell, capturing water molecules, creating there an increased osmotic pressure, which leads to its lysis. Membrane pores have considerably better permeability to small water molecules than to larger urea molecules, therefore the erythrocyte membrane permeability (EMP) test for urea is more sensitive [9].

The purpose of the study was to assess the effect of treatment the contact surface extracorporeal circuit with «adaptation composition» (AdC) on changes in the state of erythrocytes after open-heart surgery with cardiopulmonary bypass (CPB).

\section{MATERIALS AND METHOD}

On the basis of the surgical center of SIS «RPC PCM» SAD adult patients were operated with CPB by the cardiac surgery team. A total of 90 patients were enrolled. This study complied with the ethic committee approval and written informed consent was obtained from patients. $\mathrm{Pa}-$ tients were divided into two groups. The group 1 (45 patients, 39/6 male/female correspondingly) included patients who underwent surgery without treatment of extracorporeal circuit by adaptation composition. Complete analysis results of group 1 before, during and after CPB is shown in tab.1. The group 2 (45 patients, 39/6 male/female correspondingly) included patients who underwent surgery with the treatment of an extracorporeal circuit with adaptation composition. Complete analysis results of group 2 before, during and after CPB is shown in tab. 2 The age of patients in both groups ranged from $68 \pm 13$ years. The weight of patients ranged from 55 to $115 \mathrm{~kg}$, with an average 
of $86.4 \pm 5.85 \mathrm{~kg}$. According to the classification system of the New York Heart Association (NYHA), patients were distributed: III FC $n=75$ (68.2\%), II FC $n=35$ (31.8\%). Coronary artery bypass grafting (CABG) was performed with ventricular fibrillation, $\mathrm{n}=89(80,9 \%)$, the rest of the surgeries (cardiac valve surgeries), $\mathrm{n}=21$ (19.1\%), performed using cardioplegic solution «Custodiol». The mean CPB time was $95.65 \pm 12.18 \mathrm{~min}$. In the group with «Custodiol» mean aortic cross-clamp time was $74.3 \pm 12.5 \mathrm{~min}$. The perfusion system used a membrane oxygenator, roller pump, nonpulsatile flow and the primed circuit 1.3-1.6 1. to achieve moderate hemodilution ( $\mathrm{Ht}-25 \pm 2$ г/л).

Hyperosmolar prime volume with an osmolarity of 510.9 mosmol/1 was used [11]. The AdC was prepared according to the proposed methodology [12]. The mean blood flow and mean arterial blood pressure were targeted at $2.5 \mathrm{~L} / \mathrm{min} / \mathrm{m}^{2}$ and $60-80 \mathrm{mmHg}$, correspondingly. $\mathrm{CPB}$ was administrated in conditions with moderate systemic hypothermia $\left(32-33^{\circ} \mathrm{C}\right)$.

The oxygenator was treated with $\mathrm{AdC}$ according to the pattern: before surgery, $20 \mathrm{ml}$ of subclavian vein patient blood was collected. The blood was sedimentation for $15 \mathrm{~min}$. to form a clot, then to obtain the serum it was centrifuged using a centrifuge NF 200 (Nuve, Turkey) for 7 minutes at $3500 \mathrm{rpm}$. The obtained serum of 5-10 $\mathrm{ml}$ was taken with a sterile syringe, adjusted to a volume of $20 \mathrm{ml}$ with saline $(0,9 \% \mathrm{NaCl})$ and add into the oxygenator (pre-filled with $0,9 \% \mathrm{NaCl}$ in a volume of $1000 \mathrm{ml}$ ) through a disposable membrane filter with pores $0.22 \mu \mathrm{m}$ (Minisart, Sartoriusstedium, Biotech corp.) Subsequently, the AdC was circulated at idle operating mode for 5-7 minutes. Then the content of the oxygenator was completely drained and then carried out the standard procedure of filling the oxygenator with corresponding solutions.

According to the study protocol, patient blood was sampling for complete blood cell count (CBC) and cytological analysis at 4 stages of surgery: before surgery, at $10 \mathrm{~min}$. CPB-time, at $60 \mathrm{~min}$. CPB-time (rewarming stage) and after separation from CPB.

CBC was carried out on the hemolytic analyzer of Swelab Alfa Basic (Sweden) which allows us to estimate the size of erythrocytes.

The electrophoretic analysis of the composition of $\mathrm{AdC}$ was accomplished before and after the treatment of an oxygenator at the Institute of Biochemistry. O. V. Palladin NAS of Ukraine in the department of protein structure.

Plasma free hemoglobin (plfHb) concentration was measured using the hemoglobincyanide method.

Erythrocytes osmotic resistance was carried out by the method of Gottfried and Robertson to determine the time up to $50 \%$ hemolysis of a blood sample in a buffer hypotonic glycerol-saline mixture in one tube.

Mechanical resistance of erythrocytes. The method of Y. V. Ganitkevich, L. I. Chernenko in its own modifi- cation was applied to determine mechanical resistance of erythrocytes, recording the concentration of plasma free hemoglobin in a $2 \%$ suspension of erythrocytes (diluent Ringer's solution, buffered HEPES [ $\mathrm{pH}=7.4]$ and containing $0,1 \%$ glucose), subjected to mechanical impact, by centrifugation for $30 \mathrm{~min}$ at $1500 \mathrm{rpm}$. The result was expressed as\% of hemolyzed cells after mechanical exposure, taking for $100 \%$ hemolysis the content of plfHb in $2 \%$ hemolysate of erythrocytes (diluent was distilled water).

Erythrocyte membrane permeability (EMP) for low molecular weight hydrophilic substances was determined using the method of urea hemolysis [13]. The method involves increasing the concentration of urea (osmotically active and does not penetrate through the intact membrane) in a series of buffered hypotonic solutions. We studied the degree of increase in hemolysis depending on the concentration of urea and thus judged the degree of damage to the erythrocyte membrane.

Acid hemolysis. The essence of the method is that $2 \mathrm{ml}$ of $0.004 \mathrm{M} \mathrm{HCl}$ solution is added in a cuvette with $20 \mathrm{~mm}^{3}$ of blood and $2 \mathrm{ml}$ of saline and than the time at which $100 \%$ hemolysis of erythrocytes occurs is calculated.

Statistical analysis. MedStart software program was used for the statistical analyses. We checked for normality of data before further analysis; $p$-values were calculated for continuous variables using the Student's test. Group differences were considered statistically significant with a $\mathrm{p}$-value of $<0.05$.

\section{RESULTS AND DISCUSSION}

Electrophoresis. Separation of the proteins that are a part of the $\mathrm{AdC}$ before and after oxygenator treatment is shown in Fig. 1, where changes in albumin concentration in the original AdC solution and after circulation at idle operating mode for 5 minutes are clearly observed. So, on the path № 1, the molecular mass is marked; path № 2 and 4 correspond to $\mathrm{AdC}$ at a dilution of 1: 200, that was added to the oxygenator; path № 3 and 5 correspond to AdC after 5 minutes of circulation in an extracorporeal circuit at idle operating mode. The albumin impoverishment is the indication of its utilization to create a nanolayer coating on the surface extracorporeal circuit and there is sufficient quantities of residual albumin in the $\mathrm{AdC}$ to produce the nanolayer.

Cytological research. These researches specify that the use of CPB influences of erythrocytes and indicate that there are changes in the shape and size of erythrocytes under the affect of CPB (fig. 2B, 3B).

In group 1, the microscopy of blood smear detects the presence of a significant number of microcytes, spherocytes and echinocytes after CPB. (fig. 2Б). The presence of irregularly shaped erythrocytes and the phenomenon of erythrocyte agglutination is also detected, which is additional evidence of their defective state. The change in the shape of erythrocytes from a «biconcave lens» to a spherocyte indicates a decrease in the effective surface area of erythrocytes (1.7 times). 


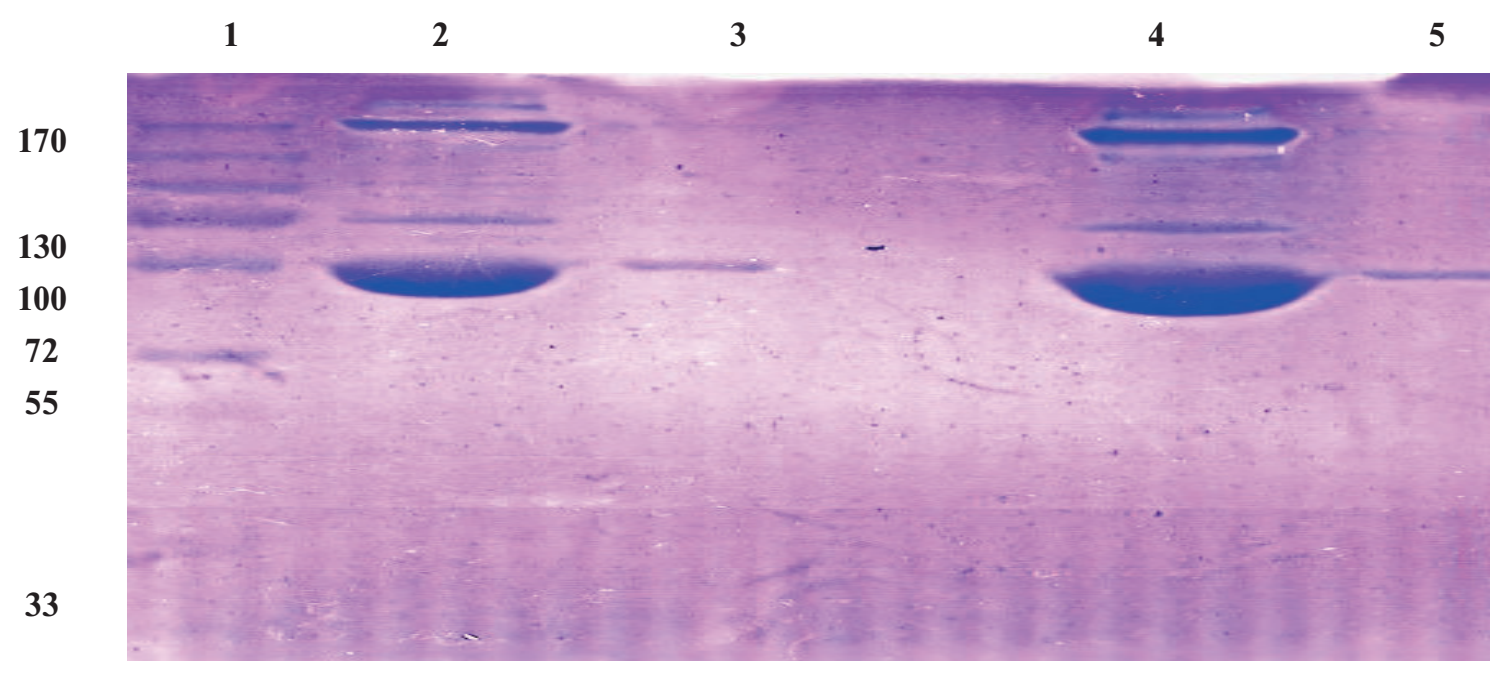

Fig. 1 Electrophoregram of separation blood proteins of original AdC and after circulation in an extracorporeal circuit at idle operating mode. 1- molecular mass marker; 2 and 4 the original AdC at a dilution of 1:200; 3 and 5 - the AdC is later 5 minutes of circulation at idle operating mode.

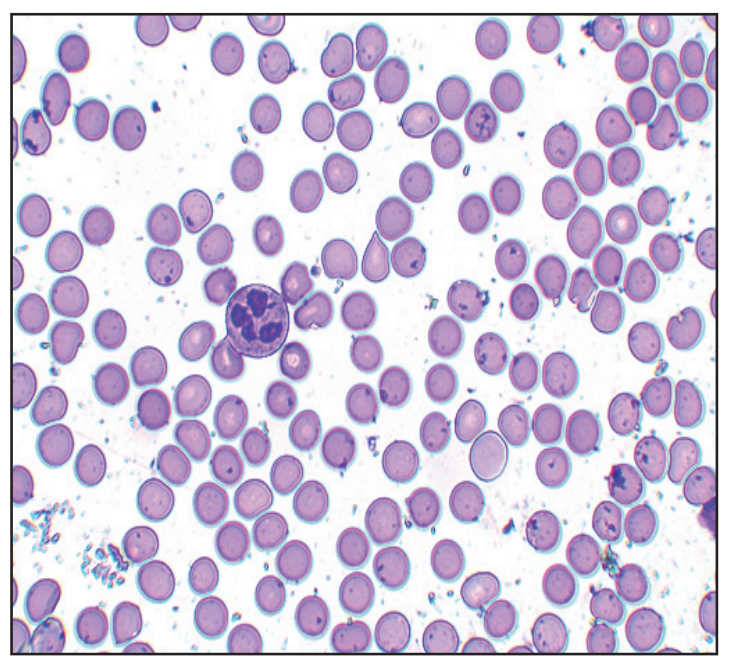

$\mathrm{A}$ - before $\mathrm{CPB}$

Fig.2 Distinctive blood smear for group 1 at different stages of surgery.

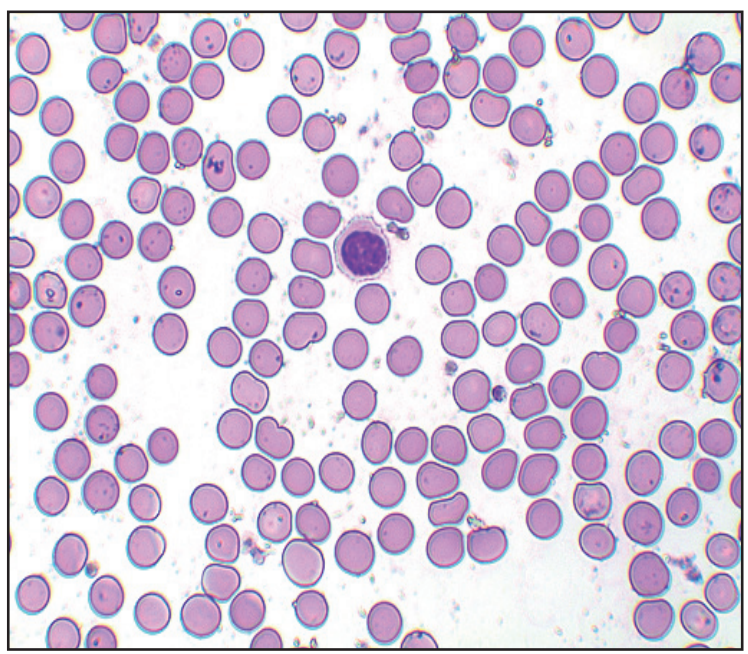

$\mathrm{A}$ - before $\mathrm{CPB}$

Fig.3 Distinctive blood smear for group 2 at different stages of surgery.

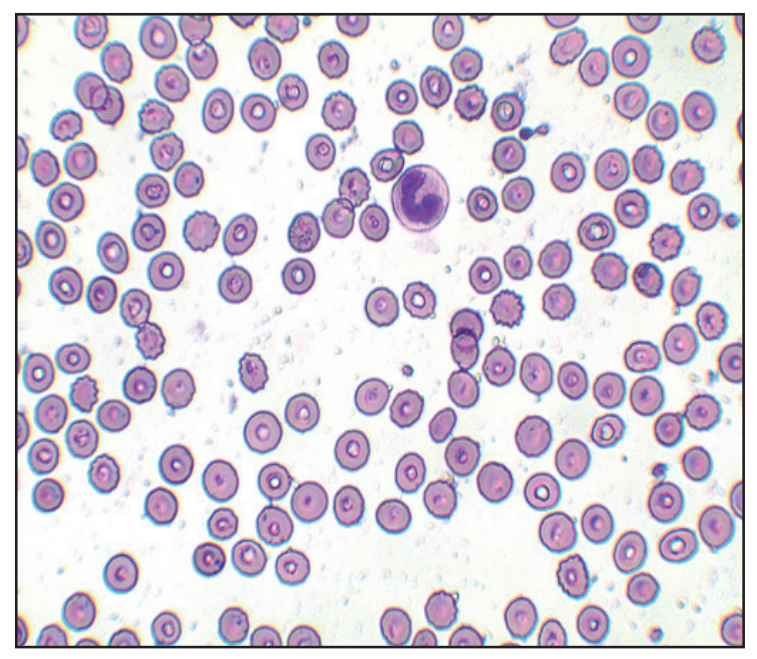

Б- after CPB

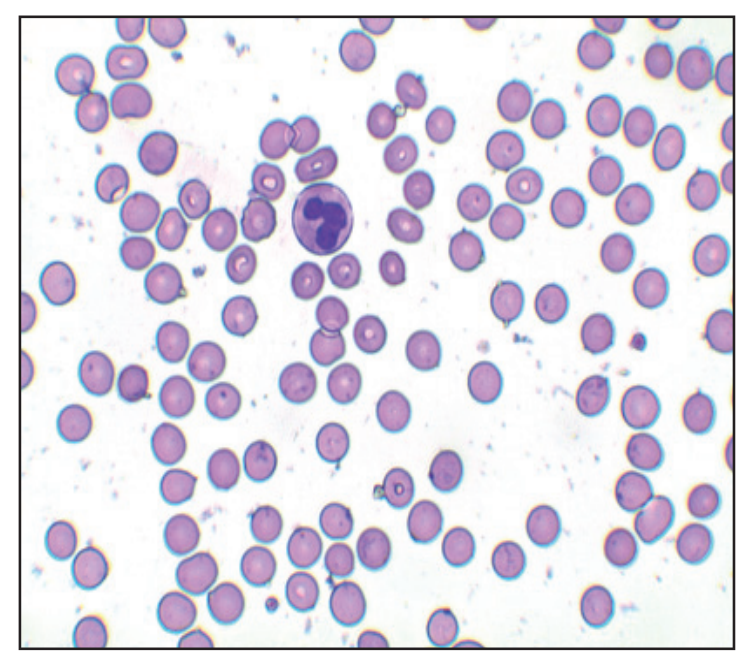

$\mathrm{B}-$ after CPB 
It can indicate the presence of certain tissue hypoxia. The loss of some erythrocytes on an oxygenator membrane and tubes due to their irreversible adsorbtion and restriction of access to the gas exchange membrane of cells leads to a decrease in oxygen supply to tissues.
The cytological research of blood samples in group 2 (with use of AdC) before and after CPB (Fig. $3 \mathrm{~A}, \mathrm{~B}$ ) indicates more preservation of erythrocytes of their shape, and only individual cells change their shape.

Parameters of red blood cells at different stages of surgery. Group $1(\mathrm{M} \pm \mathrm{m})$

\begin{tabular}{|c|c|c|c|c|c|c|c|c|}
\hline Parameter & Before CPB & $\begin{array}{c}\text { 10 min. } \\
\text { CPB-time }\end{array}$ & $\mathbf{p}$ & $\begin{array}{c}\text { 60 min. } \\
\text { CPB-time } \\
\text { (rewarming) }\end{array}$ & $p^{*}$ & After CPB & $p^{* *}$ & $p^{* * *}$ \\
\hline $\mathrm{RBC}$ & $4.57 \pm 0.43$ & $3.08 \pm 0.31$ & $<0.0001$ & $2.94 \pm 0.42$ & 0.096 & $3.69 \pm 0.32$ & $<0.0001$ & $<0.0001$ \\
\hline $\mathrm{Hb}$ & $133.18 \pm 11.31$ & $83.14 \pm 19.02$ & $<0.0001$ & $85.33 \pm 9.98$ & 0.360 & $109.25 \pm 22.69$ & 0.0002 & $<0.0001$ \\
\hline $\mathrm{Ht}$ & $40.44 \pm 4.01$ & $24.49 \pm 3.32$ & $<0.0001$ & $25.44 \pm 3.9$ & 0.073 & $33.01 \pm 1.70$ & $<0.0001$ & $<0.0001$ \\
\hline $\mathrm{Hemolysis}$ & $0.16 \pm 0.08$ & $0.18 \pm 0.08$ & 0.126 & $0.39 \pm 0.17$ & $<0.0001$ & $0.51 \pm 0.19$ & $<0.0001$ & $<0.0001$ \\
\hline $\mathrm{MCV}$ & $86.78 \pm 3.49$ & $82.34 \pm 4.93$ & 0,0068 & $84.88 \pm 4.37$ & 0.01 & $88.29 \pm 4.25$ & $<0.0001$ & 0.002 \\
\hline $\mathrm{MCH}$ & $28.76 \pm 1.32$ & $29.50 \pm 2.71$ & 0.121 & $28.76 \pm 1.77$ & 0.400 & $29.48 \pm 1.17$ & 0.061 & 0.450 \\
\hline $\mathrm{MCHC}$ & $332.57 \pm 14.22$ & $348.61 \pm 23.21$ & 0.008 & $330.38 \pm 16.38$ & 0.611 & $325.14 \pm 21.16$ & 0.013 & $<0.0001$ \\
\hline $\mathrm{RDW} \%$ & $13.08 \pm 0.83$ & $13.11 \pm 1.03$ & 0.559 & $12.46 \pm 0.70$ & 0.025 & $13.75 \pm 1.09$ & $<0.0001$ & 0.001 \\
\hline $\mathrm{RDWa}$ & $74.91 \pm 7.32$ & $74.40 \pm 6.80$ & 0.134 & $72.35 \pm 7.26$ & 0.010 & $77.56 \pm 7.13$ & $<0.0001$ & $<0.0001$ \\
\hline
\end{tabular}

$p$-significance level in comparison parameters before CPB and at $10 \mathrm{~min}$. CPB-time; $p^{*}$ - significance level in comparison parameters at $10 \mathrm{~min}$. CPB-time and $60 \mathrm{~min}$. CPB-time (rewarming); $p^{* *}$ - significance level in comparison parameters at $60 \mathrm{~min}$. CPB-time (rewarming) and after CPB; $p^{* * *}$ - significance level in comparison parameters before CPB and after CPB.

Parameters of red blood cell at different stages of surgery. Group 2 ( $(M \pm m)$

\begin{tabular}{|c|c|c|c|c|c|c|c|c|}
\hline Parameter & Before CPB & $\begin{array}{c}\text { 10 min. } \\
\text { CPB-time }\end{array}$ & $p$ & $\begin{array}{c}\text { 60 min. } \\
\text { CPB-time } \\
\text { (rewarming) }\end{array}$ & $p^{*}$ & After CPB & $p^{* *}$ & $p^{* * *}$ \\
\hline RBC & $4.63 \pm 0.54$ & $3.04 \pm 0.50$ & $<0.0001$ & $3.13 \pm 0.72$ & 0.148 & $3.74 \pm 0.45$ & 0.002 & $<0.0001$ \\
\hline $\mathrm{Hb}$ & $130.38 \pm 12.91$ & $84.41 \pm 15.35$ & $<0.0001$ & $89.85 \pm 14.72$ & 0.096 & $105.65 \pm 29.57$ & $<0.0001$ & $<0.0001$ \\
\hline $\mathrm{Ht}$ & $39.54 \pm 4.11$ & $24.92 \pm 4.55$ & $<0.0001$ & $26.05 \pm 4.26$ & 0.161 & $32.45 \pm 4.89$ & $<0.0001$ & $<0.0001$ \\
\hline Hemolysis & $0.13 \pm 0.06$ & $0.15 \pm 0.06$ & 0.170 & $0.33 \pm 0.13$ & $<0.0001$ & $0.42 \pm 0.11$ & 0.0002 & $<0.0001$ \\
\hline MCV & $85.40 \pm 3.81$ & $81.19 \pm 4.00$ & $<0.0001$ & $82.32 \pm 3.40$ & 0.174 & $86.79 \pm 2.54$ & $<0.0001$ & 0.331 \\
\hline MCH & $29.39 \pm 1.24$ & $28.68 \pm 1.56$ & 0.288 & $29.89 \pm 1.72$ & 0.334 & $29.10 \pm 1,59$ & 0.088 & 0.658 \\
\hline MCHC & $333.52 \pm 10.32$ & $342.07 \pm 11.32$ & 0.013 & $338.23 \pm 12.33$ & 0.215 & $332.14 \pm 12.49$ & 0.038 & 0.189 \\
\hline RDW\% & $13.30 \pm 0.90$ & $13.09 \pm 0.95$ & 0.471 & $13.37 \pm 0.93$ & 0.789 & $13.57 \pm 0.85$ & 0.478 & 0.816 \\
\hline RDWa & $77.61 \pm 5.84$ & $76.10 \pm 4.83$ & 0.189 & $76.05 \pm 5.46$ & 0.400 & $75.66 \pm 5.12$ & 0.709 & 0.256 \\
\hline
\end{tabular}

$\mathrm{p}$ - significance level in comparison parameters before CPB and at $10 \mathrm{~min}$. CPB-time; $\mathrm{p}^{*}$ - significance level in comparison parameters at $10 \mathrm{~min}$. CPB-time and $60 \mathrm{~min}$. CPB-time (rewarming); $\mathrm{p}^{* *}$ - significance level in comparison parameters at $60 \mathrm{~min}$. CPB-time (rewarming) and after CPB; $\mathrm{p}^{* * *}$ - significance level in comparison parameters before CPB and after CPB.

The complete blood cells. A comparison of the studied results of hematological indexes, showed that at 10 min. cardiopulmonary bypass time (CPB-time) there is a statistically significant decrease in $\mathrm{Hв}, \mathrm{Ht}$ and erythrocytes both group 1 and group $2(\mathrm{p}<0.0001)$ due to hemodilution. After surgery in 1 and 2 groups the in- crease in $\mathrm{Hb}$ is noted, in comparing two groups, parameters were statistically not significant $(p=0,907)$ in spite of the fact that in 1 group hemolysis was higher $(p<0.0001)$. Possibly it is because of more peripheralization of reticulocytes in group 1 compared with group $2(\mathrm{p}<0.0001)$. 
Comparisons of parameters of a red blood cell and dynamics of change of erythrocytes shape between group 1 and group $2(\mathrm{M} \pm \mathrm{m})$

\begin{tabular}{|c|c|c|c|c|c|c|c|c|c|c|c|c|}
\hline Parametr & $\begin{array}{c}\text { Before } \\
\text { CPB } \\
\text { Group } 2\end{array}$ & $\begin{array}{c}\text { Before } \\
\text { CPB } \\
\text { Group } 1\end{array}$ & $p$ & $\begin{array}{c}10 \text { min. } \\
\text { CPB- } \\
\text { time } \\
\text { Group } 2\end{array}$ & $\begin{array}{c}10 \text { min. } \\
\text { CPB- } \\
\text { time } \\
\text { Group } 1\end{array}$ & $p^{*}$ & $\begin{array}{c}60 \text { min. } \\
\text { CPB-time } \\
\text { (rewarming) } \\
\text { Group } 2 \\
\end{array}$ & $\begin{array}{c}60 \text { min. } \\
\text { CPB-time } \\
\text { (rewarming) } \\
\text { Group } 1\end{array}$ & $p^{* *}$ & $\begin{array}{c}\text { After } \\
\text { CPB } \\
\text { Group } 2\end{array}$ & $\begin{array}{c}\text { After } \\
\text { CPB } \\
\text { Group } 1\end{array}$ & $p^{* * *}$ \\
\hline $\mathrm{RBC}$ & $\begin{array}{c}4.63 \pm \\
0.54\end{array}$ & $\begin{array}{c}4.57 \pm \\
0.43\end{array}$ & 0.071 & $\begin{array}{c}3.04 \pm \\
0.50\end{array}$ & $\begin{array}{c}3.08 \pm \\
0.31\end{array}$ & 0.532 & $\begin{array}{c}3,13 \pm \\
0,72\end{array}$ & $2,94 \pm 0,42$ & 0,051 & $\begin{array}{c}3,74 \pm \\
0,45\end{array}$ & $\begin{array}{c}3,69 \pm \\
0,32\end{array}$ & 0,648 \\
\hline $\mathrm{Hb}$ & $\begin{array}{c}130.38 \pm \\
12.91\end{array}$ & $\begin{array}{c}133.18 \pm \\
11.31\end{array}$ & 0.334 & $\begin{array}{c}84.41 \pm \\
15.35\end{array}$ & $\begin{array}{c}83.14 \pm \\
19.02\end{array}$ & 0.591 & $\begin{array}{c}89.85 \pm \\
14.72\end{array}$ & $\begin{array}{c}85.33 \pm \\
9.98\end{array}$ & 0.062 & $\begin{array}{r}105.65 \\
\pm 29.57\end{array}$ & $\begin{array}{c}109.25 \pm \\
22.69\end{array}$ & 0.907 \\
\hline $\mathrm{Ht}$ & $\begin{array}{c}39.54 \pm \\
4.11\end{array}$ & $\begin{array}{c}40.44 \pm \\
4.01\end{array}$ & 0.418 & $\begin{array}{c}24.92 \pm \\
4.55\end{array}$ & $\begin{array}{c}24.49 \pm \\
3.32\end{array}$ & 0.659 & $\begin{array}{c}26.05 \pm \\
4.26\end{array}$ & $\begin{array}{c}25.44 \pm \\
3.90\end{array}$ & 0.021 & $\begin{array}{c}32.45 \pm \\
4.89\end{array}$ & $\begin{array}{c}33.01 \pm \\
1.70\end{array}$ & 0.035 \\
\hline Hemolysis & $\begin{array}{c}0.13 \pm \\
0.06\end{array}$ & $\begin{array}{c}0.16 \pm \\
0.08\end{array}$ & 0.061 & $\begin{array}{c}0.15 \pm \\
0.06\end{array}$ & $\begin{array}{c}0.18 \pm \\
0.08\end{array}$ & 0.092 & $\begin{array}{c}0.33 \pm \\
0.13\end{array}$ & $0.39 \pm 0.17$ & $<0.0001$ & $\begin{array}{c}0.42 \pm \\
0.11\end{array}$ & $\begin{array}{c}0.51 \pm \\
0.19\end{array}$ & $<0.0001$ \\
\hline $\mathrm{MCV}$ & $\begin{array}{c}85.40 \pm \\
3.81\end{array}$ & $\begin{array}{c}86.78 \pm \\
3.49\end{array}$ & 0.381 & $\begin{array}{c}81.19 \pm \\
4.00\end{array}$ & $\begin{array}{c}82.34 \pm \\
4.93\end{array}$ & 0.368 & $\begin{array}{c}82.32 \pm \\
3.40\end{array}$ & $\begin{array}{c}84.88 \pm \\
4.37\end{array}$ & 0.025 & $\begin{array}{c}86.79 \pm \\
2.54\end{array}$ & $\begin{array}{c}88.29 \pm \\
4.25\end{array}$ & $<0.0001$ \\
\hline $\mathrm{MCH}$ & $\begin{array}{c}29.39 \pm \\
1.24\end{array}$ & $\begin{array}{c}28.76 \pm \\
1.32\end{array}$ & 0.113 & $\begin{array}{c}28.68 \pm \\
1.56\end{array}$ & $\begin{array}{c}29.50 \pm \\
2.71\end{array}$ & 0.487 & $\begin{array}{c}29.89 \pm \\
1.72\end{array}$ & $\begin{array}{c}28.76 \pm \\
1.77\end{array}$ & 0.780 & $\begin{array}{c}29.10 \pm \\
1.59\end{array}$ & $\begin{array}{c}29.48 \pm \\
1.17\end{array}$ & 0.114 \\
\hline $\mathrm{MCHC}$ & $\begin{array}{c}333.52 \pm \\
10.32\end{array}$ & $\begin{array}{c}332.57 \pm \\
14.22\end{array}$ & 0.137 & $\begin{array}{c}342.07 \\
\pm 11.32\end{array}$ & $\begin{array}{c}348.61 \pm \\
23.21\end{array}$ & 0.149 & $\begin{array}{c}338.23 \pm \\
12.33\end{array}$ & $\begin{array}{c}330.38 \pm \\
16.38\end{array}$ & 0.925 & $\begin{array}{c}332.14 \pm \\
12.49\end{array}$ & $\begin{array}{c}325.14 \pm \\
21.16\end{array}$ & $<0.0001$ \\
\hline RDW\% & $\begin{array}{c}13.30 \pm \\
0.90\end{array}$ & $\begin{array}{c}13.08 \pm \\
0.83\end{array}$ & 0.421 & $\begin{array}{c}13.09 \pm \\
0.95\end{array}$ & $\begin{array}{c}13.11 \pm \\
1.03\end{array}$ & 0.560 & $\begin{array}{c}13.37 \pm \\
0.93\end{array}$ & $\begin{array}{c}12.46 \pm \\
0.70\end{array}$ & $<0.0001$ & $\begin{array}{c}13.57 \pm \\
0.85\end{array}$ & $\begin{array}{c}13.75 \pm \\
1.09\end{array}$ & 0.323 \\
\hline RDW a & $\begin{array}{c}77.61 \pm \\
5.84\end{array}$ & $\begin{array}{c}74.91 \pm \\
7.32\end{array}$ & 0.08 & $\begin{array}{c}76.10 \pm \\
4.83\end{array}$ & $\begin{array}{l}74.40 \\
\pm 6.80\end{array}$ & 0.078 & $\begin{array}{c}76.05 \pm \\
5.46\end{array}$ & $\begin{array}{c}72.35 \pm \\
7.26\end{array}$ & $\begin{array}{c}< \\
0.0001\end{array}$ & $\begin{array}{c}75.66 \pm \\
5.12\end{array}$ & $\begin{array}{l}77.56 \\
\pm 7.13\end{array}$ & 0.021 \\
\hline $\begin{array}{c}\text { Reticulocytes, } \\
\%\end{array}$ & $\begin{array}{c}1.41 \pm \\
0.64\end{array}$ & $\begin{array}{c}1.37 \pm \\
0.60\end{array}$ & 0.762 & - & - & - & - & - & - & $\begin{array}{c}3.51 \pm \\
1.19\end{array}$ & $\begin{array}{c}5.19 \pm \\
1.46\end{array}$ & $<0.0001$ \\
\hline $\begin{array}{c}\text { Echinocytes, } \\
\%\end{array}$ & $\begin{array}{c}5.32 \pm \\
0.79\end{array}$ & $\begin{array}{c}5.10 \pm \\
0.79\end{array}$ & 0.200 & - & - & - & - & - & - & $\begin{array}{c}7.16 \pm \\
0.84\end{array}$ & $\begin{array}{c}9.79 \pm \\
1.89\end{array}$ & $<0.0001$ \\
\hline $\begin{array}{c}\text { Spherocytes, } \\
\%\end{array}$ & $\begin{array}{c}0.73 \pm \\
0.30\end{array}$ & $\begin{array}{c}0.72 \pm \\
0.32\end{array}$ & 0.894 & - & - & - & - & - & - & $\begin{array}{c}2.19 \pm \\
0.74\end{array}$ & $\begin{array}{c}2.66 \pm \\
1.17\end{array}$ & $<0.0001$ \\
\hline
\end{tabular}

$\mathrm{p}$ - significance level in comparison parameters before CPB and at $10 \mathrm{~min}$. CPB-time; $\mathrm{p}^{*}$ - significance level in comparison parameters at $10 \mathrm{~min}$. CPB-time and $60 \mathrm{~min}$. CPB-time (rewarming); $\mathrm{p}^{* *}$ - significance level in comparison parameters at 60 min. CPB-time (rewarming) and after CPB; $\mathrm{p}^{* * *}$ - significance level in comparison parameters before CPB and after CPB.

Level of Ht 1 (group 1) and Ht 2 (in group 2) being compared at 60 min CPB-time and after CPB, it is shown that $\mathrm{Ht} 2$ was statistically lower than $\mathrm{Ht} 1$ at these stages $(p=0.021$ and $p=0.035$ respectively). Simultaneously, at 60 min CPB-time and after CPB there was no statistical differences between $\mathrm{Hb} 1$ and $\mathrm{Hb} 2(\mathrm{p}=0.062$ and $\mathrm{p}=0.907$ respectively). We suggest that it is possible by significantly increasing the MCV 1 compared to MCV 2 (group 2) at these stages ( $p=0.025$ and $p<0.0001$ respectively).

Decline of mean corpuscular volume $(\mathrm{MCV})$ at 10 minutes CPB-time as in group 1 (MCV 1) 82.34 \pm 4.93 ; $\mathrm{p}=0.0068$ and in group $2(\mathrm{MCV} 2) 81.19 \pm 4.00 ; \mathrm{p}<0.0001$ attracts attention. It is possible due to the use of the hyperosmolar primary solution, and this MCV remain within the physiologically normal state. There is no significant difference in MCV at $10 \mathrm{~min}$. CPB-time between group 1 and group $2(\mathrm{p}=0.381)$. It demonstrates that the prime composition of equal influences of erythrocytes in two groups. There are differences $\mathrm{p}=0.025$ between $\mathrm{MCV} 1$ and MCV 2 at 60 min. CPB-time (rewarming) and $\mathrm{p}<0.0001$ between MCV 1 and MCV 2 after CPB. Also there are an increase in the mean corpuscular hemoglobin concentration $(\mathrm{MCHC} 2)(\mathrm{p}=0.013)$ in group 2 and in group 1 (MCHC1) $(\mathrm{p}=0.008)$ at $10 \mathrm{~min}$. CPB-time. Possibly, this relative increase in parameters due to decrease MCV at 10 min CPB-time in group $1(\mathrm{p}=0.0068)$ and group 2 $(\mathrm{p}<0.0001)$. Again, the two groups being compared with each other and changes in MCV, MCH, MCHC at 10 minutes are statistically insignificant (tab. 3) that is indicative of an equal change in parameters from the beginning $\mathrm{CPB}$ in the two groups. MCHC1 being compared at $60 \mathrm{~min}$. CPB-time and after CPB, there is a difference $\mathrm{p}=0.013$. There is a significance difference between $\mathrm{MCHC} 1$ before CPB and MCHC1 after perfusion ( $\mathrm{p}<0.0001)$. MCHC1 and $\mathrm{MCHC} 2$ being compared after $\mathrm{CPB}$, causes there a significant decrease in the MCHC1 $(\mathrm{p}<0.0001)$.

Studying parameters of MCV after CPB by comparison before initiation of CPB suggested that an increase MCV was caused in group $1(\mathrm{p}=0.002)$ but this value does not differ $(\mathrm{p}=0.331)$ in group 2 and decrease in MCV at 10 min. CPB-time $(81.19 \pm 4.00)$ returns to the basal value. 
At 10 min. CPB-time in group 1 the red blood cell distribution width parameter (RDWa1) was caused $74.40 \pm 6.80$ and there was no significant difference between average values in comparison with basal value $(\mathrm{p}=0.134)$. The same situation was in group 2 . RDWa2 was $76.10 \pm 4.83(\mathrm{p}=0.189)$. Group 1 and group 2 being compared at $10 \mathrm{~min}$. CPB-time, there was no significant difference between average values $(p=0.078)$ but there were significant differences between RDWa 1 and RDWa 2 at 60 min. CPB-time $(\mathrm{p}<0.0001)$ and RDWa 1 and RDWa 2 after $\operatorname{CPB}(\mathrm{p}=0.021)$.

At $60 \mathrm{~min}$. CPB-time (rewarming stage), when comparing there is a change of RDW\% $13.37 \pm 0.93$ (group 2) and $12.46 \pm 0.70$ (group 1 ); $\mathrm{p}<0.0001$ and RDWa $76.05 \pm 5.46$ (group 2), $72.35 \pm 7.26$ (group 1$) ; \mathrm{p}<0.0001$, at the same time in group 1 the tendency to decrease in RDWa is observed up to 60 min CPB-time $(p=0.010)$, it is possible due to more destruction macro - and microcytes on oxygenator membranes. This is consistent with higher hemolysis in group 1 compared with group 2 $(\mathrm{p}<0.0001)$ at $60 \mathrm{~min}$. In group 1 there are a statistically significant increase in RDWa1 after CPB in comparison with 60 min CPB-time $(\mathrm{p}<0.0001)$. Probably this is due to an increase in the pool of reticulocytes in the peripheral blood $(5.19 \pm 1.46)$, as a reaction to more pronounced hemolysis and tissue hypoxia. CPB-time. There are significant differences $\mathrm{p}<0.0001$ between RDWa 1 before and after CPB.

In the study of the morphology of erythrocytes, it was found that the initial\% content of reticulocytes, echinocytes and spherocytes of the two groups was not statistically significant (Tab. 3). After CPB in group 1 the higher content of reticulocytes $(\mathrm{p}<0.0001)$, echinocytes $(\mathrm{p}<0.0001)$ and spherocytes $(\mathrm{p}<0.0001)$ is observed in the peripheral blood in comparison with group 2 .

Tab. 4

Parameters of erythrocyte resistance before and after CPB $(M \pm m)$

\begin{tabular}{|l|c|c|c|c|}
\hline \multicolumn{2}{|c|}{ Parameter } & Group 1 & Group 2 & p \\
\hline \multirow{2}{*}{ Mechanical resistance of erythrocytes, $\%$} & Before surgery & $59.90 \pm 18.21$ & $45.28 \pm 20.48$ & 0.234 \\
\cline { 2 - 5 } & After surgery & $89.93 \pm 19.87$ & $61.38 \pm 16.33$ & 0.040 \\
\hline \multirow{2}{*}{ Time of acid hemolysis 50\% of erythrocytes, sec. } & Before surgery & $230.39 \pm 36.91$ & $243.35 \pm 38.92$ & 0.104 \\
\cline { 2 - 5 } & After surgery & $134.48 \pm 35.3$ & $146.37 \pm 22.82$ & 0,05 \\
\hline \multirow{2}{*}{ Osmotic resistance of erythrocytes, sec. } & Before surgery & $448.2 \pm 218.4$ & $520.7 \pm 319.05$ & 0.206 \\
\cline { 2 - 5 } & After surgery & $263.9 \pm 140.41$ & $345.1 \pm 173.56$ & 0.01 \\
\hline
\end{tabular}

$\mathrm{p}$ - significance level in comparison parameters before CPB and after CPB.

Parameters of erythrocyte membrane permeability (TEM) for urea solution before and after CPB (M $\pm m$ )

\begin{tabular}{|c|c|c|c|c|c|c|}
\hline \multirow{2}{*}{$\begin{array}{c}\text { No } \\
\text { tube }\end{array}$} & \multicolumn{3}{|c|}{ TEM\%, before CPB } & \multicolumn{3}{c|}{ TEM\%, after CPB } \\
\cline { 2 - 8 } & Group 1 & Group 2 & $\mathbf{p}$ & Group 1 & Group 2 & $\mathbf{p}^{*}$ \\
\hline $1(40: 60) *$ & $43.87 \pm 4.32$ & $42.91 \pm 3.18$ & 0.583 & $42.44 \pm 3.84$ & $43.46 \pm 4.53$ & 0.749 \\
\hline $2(45: 55)$ & $47.45 \pm 5.26$ & $46.09 \pm 6.07$ & 0.656 & $46.82 \pm 4.75$ & $47.74 \pm 3,91$ & 0.818 \\
\hline $3(50: 50)$ & $73.10 \pm 6.15$ & $60.38 \pm 7.98$ & 0.097 & $69.44 \pm 9.84$ & $65.85 \pm 8.88$ & 0.05 \\
\hline $4(55: 45)$ & $86.43 \pm 6.97$ & $79.17 \pm 8.32$ & 0.076 & $81.78 \pm 7.18$ & $78.58 \pm 9,66$ & 0.041 \\
\hline $5(60: 40)$ & $91.43 \pm 4.35$ & $87.23 \pm 5.06$ & 0.209 & $90.47 \pm 5.59$ & $86.79 \pm 4.72$ & 0.003 \\
\hline $6(65: 35)$ & $95.08 \pm 2.24$ & $88.99 \pm 3.87$ & 0.077 & $95.76 \pm 3.64$ & $94.89 \pm 3.89$ & 0.343 \\
\hline 7 (etalon) ${ }^{* *}$ & 1.0000 & 1.0000 & & 1.0000 & 1.0000 & \\
\hline
\end{tabular}

* The ratio of hypotonic solutions of urea and sodium chloride.

** Etalon is the content of the tube is $100 \%$ urea solution.

$\mathrm{p}$ - significance level before CPB.

$\mathrm{p}^{*}$ - significance level after CPB.

Hemolysis during extracorporeal circulation is the result of the destruction of the RBC membrane with breakdown and release of plasma free hemoglobin. There are no significant differences in the level of hemolysis between the basal value of hemolysis and at $10 \mathrm{~min}$. CPB-time in groups, beginning with $60 \mathrm{~min}$. CPB-time and after $\mathrm{CPB}$ hemolysis was higher in group $1(\mathrm{p}<0.0001)$.
The study of erythrocyte resistance in both groups the following was revealed. Parameters of mechanical resistance of red blood cells before surgery were not statistically significant between the two groups $(p=0.234)$. In group 1 after separation from $\mathrm{CPB}$, there was a decrease in the mechanical resistance of erythrocytes compared with group $2(p=0.04)$. 
The analysis of erythrocyte membrane permeability for urea solution revealed that the level of $50 \%$ erythrocytes hemolysis in urea solution after CPB starting from dilution of hypotonic solutions of urea and sodium chloride in a ratio of 50:50 was higher in group 1, the same tendency remained in dilution 55:45, 60:40 (tab. 5). It may be explained both more damage of erythrocyte membranes in the extracorporeal circuit and more release of reticulocytes (young cell forms), which contain less cholesterol, which determines the density of location lipids in the membrane, viscosity and permeability of the lipid layer.

Assessment of acid erythrocyte resistance in group 1 demonstrates the reduction in acid erythrocyte hemolysis time of $50 \%$ after surgery compared to initial parameters $(p<0.0001)$, this may be due to the lytic action of the membrane-attacking complex when the complement system is activated under conditions of blood contact with a foreign surface extracorporeal circuit. After weaning from bypass, the tendency to more resistance of erythrocytes to acid hemolysis in group 2 , in comparison with group 1 was observed $(p=0.05)$.

The study of osmotic resistance of erythrocytes (ORE) showed that in the first and second groups before surgery, ORE parameters were not statistically significant $(\mathrm{p}=0.206)$, and after CPB erythrocytes in group 2 were more resistant to hypoosmotic factor $(p=0.01)$. Decreased ORE is possible with glucose-6-phosphate dehydrogenase deficiency in erythrocytes and activation of lipid peroxidation [14]. The study in this direction continues.

\section{CONCLUSIONS}

In the research, it is confirmed that the use of the offered method (the treatment of the extracorporeal circuit by $\mathrm{AdC}$ ) leads to the reduction of negative CPB impact on the condition of erythrocytes.
1. Electrophoresis showed that the treatment of the extracorporeal circuit with AdC leads to irreversible multicenter adsorbtion of the patient's autoalbumin on the working surface of the oxygenator (membranes and tubes) from a solution of low albumin concentration.

2. Tissue hypoxia and changes in the structure and function of erythrocytes are a leading pathogenetic factor in the development of critical conditions of patients who underwent open-heart surgery. Fewer echinocytes and spherocytes in blood samples after surgery in the group with the treatment of oxygenator surface with AdC indicates the more adequate oxygen supply to erythrocytes.

3. Hemolysis level in blood plasma after surgery was higher in the group without treatment of extracorporeal circuit with adaptation composition.

4. The intensity of hemolysis depends not only on mechanical damage of erythrocytes but also on a state of erythrocytes membrane after CPB. In the group where the extracorporeal circuit was treatment with AdC, membranes of erythrocytes were more resistant to the action of damaged factors.

Conflict of interests. The authors declare no conflict of interests.

Funding information. It is public-funded research in connection with scientific research work of the department.

Ethical practices. The authors adhere to the principles contained in the Declaration of Helsinki, as well as in the Interdisciplinary Principles and Guidelines for the Use of Animals in Research, Testing and Education, published by the Special Committee on Animal Research at the New York Academy of Sciences. The study was carried out in accordance with the principles of ethics.

\section{ЛІТЕРАТУРА}

1. Grygorczyk R., Orlov S. N. The effect of hypoxia on the properties of erythrocyte membranes - importance for intravascular hemolysis and purinergic blood flow control. Front. Physiol. 2017. 22 December. https:// doi.org/10.3389/fphys.2017.01110.

2. Obstals F., Vorobii M., Riedel T., de Los Santos Pereira A., Bruns M., Singh S., Rodriguez-Emmenegger C. Improving Hemocompatibility of Membranes for Extracorporeal Membrane Oxygenators by Grafting Nonthrombogenic Polymer Brushes. Macromol Biosci. 2018. Mar. 18(3). doi: 10.1002/mabi.201700359. Epub 2018 Jan 22.

3. Andrew J. Doyle and Beverley J. Hun. Current Understanding of How Extracorporeal Membrane
Oxygenators Activate Haemostasis and Other Blood Components. Front Med (Lausanne). 2018. 5. 352.

4. Wang W., Zheng Z., Huang X., Fan W., Yu W., Zhang Z., Li L., Mao C. Hemocompatibility and oxygenation performance of polysulfone membranes grafted with polyethylene glycol and heparin by plasma-induced surface modification. J Biomed Mater Res B Appl Biomater. 2017. Oct. 105(7). 1737-1746

5. Sugita J. K. Fujiu Systemic Inflammatory Stress Response During Cardiac Surgery. Heart J. 2018. 59. 457-459.

6. Wang Y. B., Shi K. H., Jiang H. L., Gong Y. K. Significantly reduced adsorption and activation of blood components in a membrane oxygenator system 
coated with crosslinkable zwitterionic copolymer. Acta Biomater. 2016. Aug. 40. 153-161. doi: 10.1016/j. actbio.2016.02.036. Epub 2016 Mar 8.

7. Тополов П. О., Дьордяй І. С., Собанська Л. О. та інш. Вплив обробки оксигенатора адаптаційною композицією під час аортокоронарного шунтування на зміну клітин крові. Серце і судини. 2018. № 1 (61).

8. Мороз В. В., Голубев А. М., Афанасьев А. В., Кузовлев А. Н., Сергунова В. А., Гудкова О. Е., Черныш А. М. Строение и функция эритроцита в норме и при критических состояниях. Общая реаніматологія. 2012. VIII. 1. С. 52-60.

9. Мальцева И. В. Характеристика резистентности эритроцитов у кардиохирургических больных с различной степенью выраженности постперфузионного гемолиза. Бюллетень сибирской медицины. 2013. Том 12, № 1. С. 69-74.

10.Спиридонов В. Н., Борисов Ю. А., Левыкина Е. Н. и др. Кислотная, осмотическая и ультразвуковая резистентность эритроцитов больных, получавших лечение регулярным гемодиализом. Нефрология. 2004. T. 8, № 3. С. 22-31.

11.Склад розчинів для заповнення первинного об'єму оксигенатору: пат. 140427 Україна. № 201908289; заявл. 16.07.2019: опубл. 25.02.2020, бюл. № 4/2020.

12.Спосіб обробки поверхні контуру оксигенатора при кардіохірургічних операціях: пат. 140413 Україна. № 201908112; заявл. 15.07.2019; опубл. 25.02.2020, Бюл. № 4/2020.
13. Колмаков В. Н., Радченко В. Г. Значение определения проницаемости эритроцитарных мембран в диагностике хронических заболеваний печени. Терапевтический архив. 1982. № 2. С. 22-24.

14. Co Ltd «Mabela»CO Ltd MABELA Substance enhancing biocompatibility of implants with recipient body and method of its preparation patent application: European patent 2709684B1. 2016. May. 25.

15. Сахау Н. Р., Мирасаева Г. Х., Камилов Ф. Х. и др. Клинико-диагностическая оценка состояния мембран эритроцитов у больных первичным хроническим пиелонефритом. Нефрология. 2005. Т. 9, № 1. C. 47-51.

16. Mindukshev I. V., Krivoshlyk V. V., Ermolaeva E. E., Dobrylko I. A., Senchenkov E. V., Goncharov N. V., Jenkins R. O., Krivchenko A. I. Necrotic and apoptotic volume changes of red blood cells investigated by lowangle light scattering technique. International Journal of Spectroscopy. 2007. 21(2). P. 105-120.

17.Brinsfield D. E., Hopf M. A., Geering R. B., Galletti P. M. Hematological changes in long-term perfusion. J Appl Physiol. 1962. 17. 531-534. PubMed: 13873140.

18.Salim E. Olia, Timothy M. Maul, James F. Antaki, Marina V. Kameneva. Mechanical Blood Trauma in Assisted Circulation: Sublethal RBC Damage Preceding Hemolysis. Int J Artif Organs. 2016. Jun. 15. 39(4). 150-159.

\section{REFERENCES}

1. Grygorczyk, R., Orlov, S. N. (2017). The effect of hypoxia on the properties of erythrocyte membranes - importance for intravascular hemolysis and purinergic blood flow control. Front. Physiol., 22 December. https://doi.org/10.3389/fphys.2017.01110.

2. Obstals, F., Vorobii, M., Riedel, T., de Los, Santos, Pereira A., Bruns, M., Singh, S., RodriguezEmmenegger, C. (2018). Improving Hemocompatibility of Membranes for Extracorporeal Membrane Oxygenators by Grafting Nonthrombogenic Polymer Brushes. Macromol Biosci., Mar, 18(3), doi: 10.1002/ mabi.201700359. Epub 2018 Jan 22.

3. Andrew, J. Doyle, Beverley, J. Hun. (2018). Current Understanding of How Extracorporeal Membrane Oxygenators Activate Haemostasis and Other Blood Components. Front Med (Lausanne), 5, 352.

4. Wang, W., Zheng, Z., Huang, X., Fan, W., Yu, W., Zhang, Z., Li, L., Mao, C. (2017). Hemocompatibility and oxygenation performance of polysulfone membranes grafted with polyethylene glycol and heparin by plasmainduced surface modification. J Biomed Mater Res B Appl Biomater, Oct, 105(7), 1737-1746.
5. Sugita, J., Fujiu, K. (2018). Systemic Inflammatory Stress Response During Cardiac Surgery. Heart J, 59, 457-459.

6. Wang, Y. B., Shi, K. H., Jiang, H. L., Gong, Y. K. (2016). Significantly reduced adsorption and activation of blood components in a membrane oxygenator system coated with crosslinkable zwitterionic copolymer. Acta Biomater, Aug, 40, 153-161. doi: 10.1016/j. actbio.2016.02.036. Epub 2016 Mar 8.

7. Topolov, P. O., Dyorday, I. S, Sobanska, L. O. ta insh. (2018). Vplyv obrobky oksygenatora adaptatsiynoiu kompozitsieiu pid chas aortokoronarnogo shuntuvannia na zminu klityn krovi [The effect of treatment of the oxygenator with an adaptation composition during coronary artery bypass grafting on the change of blood cells]. Heart and blood vessels, 1 (61).

8. Moroz, V. V., Golubev, A. M., Afanasev, A. V., Kuzovlev, A. N., Sergunova V. A., Gudkova, O. E., Chernysh, A. M. (2012). Stroenie i fynktsiia eritrocita v norme i pri kriticheskikh sostoianiiakh [The structure and function of erythrocytes in normal and in critical conditions]. General resuscitation, VIII, 1, 52-60. 
9. Maltseva, I. V. (2013). Kharakteristika rezistentnosti eritrotsitov u kardiokhiryrgicheskikh bolnukh s razlichnoi stepeniu vyrazennosti postperfuzionnogo gemoliza [Characteristics of erythrocyte resistance in cardiomyogenic patients with different degrees of expression of postperfusion hemolysis]. Byulleten sibirskoi mediciny, 12, 1, 69-74.

10.Spiridonov, V. N., Borisov U.A., Levykina E. N. i dr. (2004). Kislotnaia, osmoticheskaia i ultrazvukovaia rezistentnost eritrotsitov bolnykh, poluchavshikh lechenie reguliarnym gemodializom [Acid, osmotic and ultrasound resistance of erythrocytes of patients with semi-inflammatory treatment by regular hemodialysis]. Nefrologiia, 8, 3, 22-31.

11.Sklad rozchyniv dlia zapovnennia pervunnogo obemu oksygenatoru (2020). [Warehouse for filling the initial volume of the oxygenator]. Pat. 140427 Ukraina. № 201908289; zaiavl. 16.07.2019; opubl. 25.02.2020, biul. № 4/2020.

12.Sposib obrobky poverkhni konturu oksygenatora pri kardiokhirurgichnych operatsiiakh (2020). [The method of surface treatment of the oxygenator circuit during cardiac surgery]. Pat. 140413 Ukraina. № 201908112; zaiavl. 15.07.2019: opubl. 25.02.2020, biul. № 4/2020.

13. Kolmakov, V. N., Radchenko, V. G. (1982). Znachenie opredeleniia pronicaemosti eritrotsitarnykh membrane v diagnostike khronicheskikh zabolevaniy pecheni [The value of determining the permeability of the erythrocyte membrane in the diagnosis of chronic liver diseases.]. Therapeutic archive, 2, 22-24.

14.Aleksyeyeva, T. A., Lazarenko, O. N. (2016). Co Ltd «Mabela» CO Ltd MABELA Substance enhancing biocompatibility of implants with recipient body and method of its preparation patent application. European patent 2709684B1. May 25.

15.Sakhau, N. R., Mirasaeva, G. Kh., Kamilov, F. Kh. i dr. (2005). Kliniko-diagnosticheskaia otsenka sostoianiia membran eritrotsitov u bolnykh pervichnym khronicheskim pielonefritom [Clinical and diagnostic assessment of the state of erythrocyte membranes in patients with primary chronic pyelonephritis]. Nephrology, 9, 1, 47-51.

16. Mindukshev, I. V., Krivoshlyk, V. V., Ermolaeva, E. E., Dobrylko, I. A., Senchenkov, E. V., Goncharov, N.V., Jenkins, R. O., Krivchenko, A. I. Necrotic and apoptotic volume changes of red blood cells investigated by lowangle light scattering technique. International Journal of Spectroscopy. 21(2) 2007., P. 105-120.

17. Brinsfield, D. E., Hopf, M. A., Geering, R. B., Galletti, P. M. (1962). Hematological changes in long-term perfusion. J Appl Physiol., 17, 531-534. PubMed: 13873140.

18. Salim, E. O., Timothy, M. M., James, F. A., Marina, V. K. (2016). Mechanical Blood Trauma in Assisted Circulation: Sublethal RBC Damage Preceding Hemolysis. Int J Artif Organs., Jun 15, 39(4), 150-159. 


\section{Резюме}

\section{ВПЛИВ ОБРОБКИ ЕКСТРАКОРПОРАЛЬНОГО КОНТУРУ ОКСИГЕНАТОРА АДАПТУЮЧОЮ КОМПОЗИЦІЄЮ (АDC) НА МОРФОЛОГІЧНІ ЗМІНИ ЕРИТРОЦИТІВ

\author{
В.І. Черній' ${ }^{1}$ Л.О. Собанська' ${ }^{1}$, О.М. Лазаренко ${ }^{1}$, Г.О. Лазаренко ${ }^{1}$, Т.А. Алєксєєва²
}

${ }^{1}$ Державна наукова установа «Науково-практичниф центр профілактичної та клінічної медицини» Державного управління справами, Київ, Україна

${ }^{2}$ Інститут хімії поверхні імені 0.0. Чуйка Національної академії наук України, Київ, Україна

В роботі висвітлюеться метод обробки экстракорпорального контура оксигенатора «адаптуючою композицією» (adaptation composition - AdC) для зменшення негативного впливу штучного кровообігу на стан еритроцитів.

Мета дослідження: встановити вплив обробки контактної поверхні оксигенатора «адаптуючою композицією» (adaptation composition - $\mathrm{AdC}$ ) на зміни стану еритроцитів при виконанні оперативних втручань на відкритому серці з використанням штучного кровообігу (ШК).

Матеріали і методи. В дослідження було включено 90 паціентів, які були розподілені на дві групи. Паціентам першої групи (45 хворих, 39/6 чол./ жін.) оперативні втручання виконували без обробки контуру оксигенатору адаптуючою композицією (AdC). Оперативні втручання у пацієнтів другої групи (45 пацієнтів - 36/9 чол./жін.) проводились з обробкою Ad C. Згідно протоколу дослідження, у пацієнтів набирали кров для загального аналізу крові та морфологічного дослідження еритроцитів на 4 етапах оперативного втручання: до початку операції, на 10 хв. ШК, на 60 хв. ШК та в кінці операції.

Результати та їх обговорення. Альбумін в складі $\mathrm{AdC}$ створюе наношар на поверхні магістралей та мембрани оксигенатора. Між групами до ШК не було статистично значущої різниці у показниках. Рівень Ht 2 (група 2) на 60 хв. ШК ти після ШК був нижче, ніж Ht 1 (група 1) (p=0,021 і p=0,035 відповід-

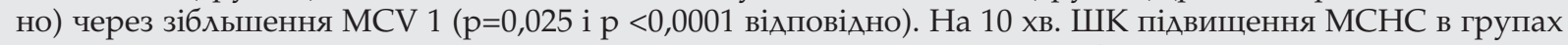
пов'язано зі зниженням MCV на 10 хв. ШК. На 60 хв. від початку ШК вілбувається зміна в RDWa2 76,05 \pm 5,46 і RDWa1 72,35 $\pm 7,26, \mathrm{p}<0,0001$. Після ШК в групі 1 визначається більш високий вміст ретикулоцитів ( $<<0,0001)$, ехіноцитів ( $\mathrm{p}<0,0001)$ і сфероцитів $(\mathrm{p}<0,0001)$. В групі 1 після ШК вілбувається зниження механічної стійкості еритроцитів $(\mathrm{p}=0,04)$ та підвищена проникність мембрани еритроцитів для сечовини. Після ШК білыша резистентність еритроцитів до кислотного гемолізу була в групі $2(p=0,05)$, також в групі 2 еритроцити були більш стійкими до гіпоосмотичному фактору $(\mathrm{p}=0,01)$.

Висновки. Обробка оксигенатора адаптуючою композицією призводить до зменшення негативного впливу ШК на стан еритроцитів. Мембрани еритроцитів були більш резистентні до Аії факторів що ушкоджують в групі з використанням Ad C.

Ключові слова: штучний кровообіг, оксигенатор, морфологія еритроцитів, аАаптуюча композиція. 


\title{
Резюме
}

\section{ВЛИЯНИЕ ОБРАБОТКИ ЭКСТРАКОРПОРАЛЬНОГО КОНТУРА ОКСИГЕНАТОРА АДАПТИРУЮЩЕЙ КОМПОЗИЦИЕЙ (АDС) НА МОРФОЛОГИЧЕСКИЕ ИЗМЕНЕНИЯ ЭРИТРОЦИТОВ \\ В.И. Черний', Л.О. Собанская' ${ }^{1}$, О.Н. Лазаренко ${ }^{1}$, Г.О. Лазаренко ${ }^{1}$, Т.А. Алексеева²}

\author{
${ }^{1}$ Государственное научное учреждение «Научно-практический центр профилактической и клинической медицины» \\ Государственного управления делами, Киев, Украина \\ ${ }^{2}$ Институт химии поверхности имени А.А. Чуйко Национальной академии наук Украины, Киев, Украина
}

В работе освещается метод обработки экстракорпорального контура оксигенатора «адаптирующей композицией» (adaptation composition - AdC) для снижения негативного влияния искусственного кровообращения на состояние эритроцитов.

Цель исследования: установить влияние обработки контактной поверхности оксигенатора «адаптирующей композицией» (AdC) на изменения состояния эритроцитов при выполнении оперативных вмешательств на открытом сердце с применением искусственного кровообращения (ИК).

Материалы и методы. В исследование было включено 90 пациентов, которые были распределены на две группы. Пациентам первой группы (45 больных, 39/6 муж. /жен.) оперативные вмешательства выполняли без обработки контура оксигенатора адаптирующей композицией (AdC). Согласно протоколу исследования, у пациентов набирали кровь для общего анализа крови и морфологического исследования эритроцитов на 4 этапах оперативного вмешательства: до начала операции, на 10 мин. ИК, на 60 мин. ИК и в конце операции.

Результаты и их обсуждение. Альбумин в составе AdC создает нанослой на поверхности мембраны оксигенатора. Между группами до ИК не было статистически значимой разницы между показателями. Уровень Ht 2 (группа 2) на 60 мин. ИК и после ИК был ниже, чем Ht 1 (группа 1) (p=0,021 и p=0,035 соответственно) за счет увеличения MCV1 ( $p=0,025$ и p <0,0001 соответственно). На 10 мин. ИК повышение MCHС в группах связано со снижением MCV на 10 мин ИК. На 60 мин. от начала ИК происходит изменение RDWa2 76,05 \pm 5,46 и RDWa1 72,35 \pm 7,26, p <0,0001. После ИК в группе 1 отмечается более высокое содержание ретикулоцитов ( $<<0,0001)$, ехиноцитов ( $<<0,0001)$ и сфероцитов $(p<0,0001)$. В группе 1 после ИК происходит снижение механической стойкости эритроцитов (р = 0,04), и повышение проницаемости мембраны эритроцитов для мочевины. После ИК большая резистентность эритроцитов к кислотному гемолизу была в группе 2 ( тическому фактору ( $\mathrm{p}=0,01)$.

Выводы. Обработка оксигенатора адаптирующей композицией приводит к уменьшению негативного влияния ИК на состояние эритроцитов. Мембраны эритроцитов были более резистентными к действию повреждающих факторов в группе с Ad C.

Ключевъе слова: искусственное кровообращение, оксигенатор, морфология эритроцитов, адаптирующая композиция.

Інформація про авторів знаходиться на сайті http://www.cp-medical.com.

Дата надходження до редакції - 10.07.2020 